\title{
Modulatory Role Of Pre- And Post- Treatment Of Spirulina Platensis On Mitomycin C Drug Induced Genotoxicity And Pathological Changes In Ehrlich Ascites Carcinoma Bearing Mature Female Swiss Albino Mice
}

\author{
Magdy F Abou-El Fotoh, Nabela I El-Sharkawy, Samah Khalil \\ and Mona M Ahmed
}

Forensic Medicine and Toxicology Dept., Faculty of Vet. Medicine, Zagazig

ABSTRACT

University

Mitomycin C (MMC) is a potent antitumor agent used against many cancers. It has a clastogenic and aneugenic effects. The protective effect of pre- and post- addition of Spirulina platensis (Sp) to the diet on MMC induced genotoxic effect and histopathological changes was evaluated in Erlich Acites Carcinoma Cell (EAC) bearing mature female Swiss albino mice. The sixty EAC bearing female albino mice weighted 30-40 gm were observed along the experimental period and classified into six equal groups. The first kept as negative control fed on Sp powder free diet. the second kept as control positive fed on Sp powder $1 \%$ in their diet 3 weeks before tumor induction (Sp1), the third group fed on Sp powder $1 \% 3$ weeks pre and one week posttumor induction (Sp1+Sp2), while the fourth group intraperitonealy (i.p) injected with MMC ( $1 \mathrm{mg} / \mathrm{kg} \mathrm{b} . w \mathrm{t})$ on the third day post tumor induction and for 7 consecutive days, while the fifth group fed on $\mathrm{Sp} 1$ in diet for 24 days before MMC injection (Sp1+MMC) and the six group fed on $\mathrm{Sp} 1$ for 24 days pre- and 7 days post MMC injection (Sp1+MMC+Sp2) as the same previous dose and manner. The end of experimental period, 7 days from MMC injection, 3 animals from each group were sacrificed after 90 minutes from I.M injection of colchicine. MMC exhibited a significant increase in the frequency of micronucleated (MN) erythrocytes concomitant with several chromosomal aberrations and multiple histopathological changes in the bone marrow, liver and kidney. Pre- and post- treatment with Sp showed potent anticlastogenic effect, regeneration of liver and kidney with restoration of bone marrow to the normal state. It can be concluded that $\mathrm{Sp}$ can minimize and mitigate the side effects of MMC on the normal cells and tissues of the body, so it can be pre- or post- treatment with MMC chemotherapy.

\section{INTRODUCTION}

Mitomycin C (MMC) is a powerful antibacterial and anti-tumour antibiotic isolated from Streptomyces caespitosus. In cancer therapy, it is a commonly used drug to fight several human malignancies including cancers of the breast, bladder, cervix, colon, lung, pancreas, rectum, stomach and uterus. It is a direct-acting clastogen requiring only intracellular reductive activation to initiate its potent DNA cross-linking action (1). MMC appears to be toxic through oxidative stress mechanism (2). Intraperitoneal injection of $2 \mathrm{mg} / \mathrm{kg}$ b.wt of MMC induced higher frequencies of micronucleus and chromosomal aberrations after 48 hours in bone marrow cells of mice (3). It induced various types of DNA damages that cause significant cytotoxicity to cells (4), although it was considered one of the most effective chemotherapeutic agents, but during clinical use several side effects may occur as genotoxicity in rat bone marrow cells (5) and renal toxicity (6). Moreover it is also carcinogenic (7), therefore strategies to protect against MMC induced genotoxicity and preserving the architecture of normal cells are of clinical interest. 
Spirulina platensis (Sp) is a type of blue green algae that has been consumed for thousands of years as a primary food source as it contains high levels of antioxidants as carotenoids especially $\beta$-carotene (8), phycocyanin and phycocyanobilin (9).Moreover Sp significantly reduced both chromosomal damage and lipid peroxidation induced by cyclophosphamide and mitomycin $\mathrm{C}$ in mice (10). Sp exhibited anti-hepatotoxic (11) and anti-nephrotoxic (12) effects. Also several studies showed that $\mathrm{Sp}$ or its extracts prevent or inhibit cancer in humans (10). The aim of this study was to investigate a possible protective effect of pre- and posttreatment with $\mathrm{Sp}$ against genotoxic and pathological effects of MMC in EAC bearing female mice.

\section{MATERIAL AND METHODS}

\section{Tested compounds}

Mitomycin C (MMC) Kyowa. Co. Ltd (Tokyo-Japan), each vial contains Mitomycin C hydrochloride $10 \mathrm{mg}$ potency, it was purchased from Eman-Elazab pharmacy, Zagazig City, Sharkia Proviance, Egypt.

Chemical formula (IUPAC):

Azirino $\quad\left(2^{\prime}, 3^{\prime}: 3,4\right)$ pyrrolo,2-aindole-4,7dione, 6-amino-1,1a,2,8,8a,8b-hexahydro-18 (hydroxymethyl)-8amethoxy-5-methylcarbamate.

Molecular formula: $\mathrm{C}_{15} \mathrm{H}_{18} \mathrm{~N}_{4} \mathrm{O}_{5}$.

Spirulina platensis $(\mathrm{Sp})$ is bright, blue-green powder. It was purchased from EL-Hellowa for Biological Products.

\section{Experimental Design}

Sixty adult female Swiss albino mice weighted 30-40 gm. were kept in metal cages under hygienic conditions, provided with food and water ad-libitum through the experiment. The animals were observed along the experimental period. Mice were i.p injection with $0.2 \mathrm{ml}$ portions of ascetic fluid containing $2.5 \times 10^{6}$ viable cells (EAC) (14), then divided into six groups of ten animals each. As shown in Table1.

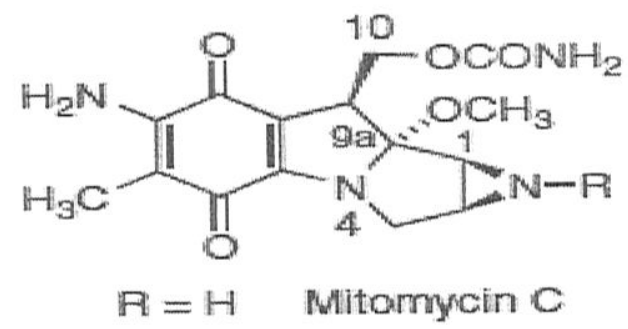

Fig.1. Chemical structure of MMC (13).

At the end of the experimental period (7days post MMC injection), 3 animals of each group were sacrificed after 90 minutes of $\mathrm{I} / \mathrm{M}$ injection of colchicine for chromosomal aberrations (17). The rest of animals were sacrificed and whole blood samples collected in EDTA containing tubes for micronucleus test (18). Femur bone, liver and kidney samples were preserved in $10 \%$ buffered neutral formalin for histopathological study and stained by Hematoxylin and Eosin (H\&E) (19).

Statistical analysis was performed using one-way analysis of variance (ANOVA) procedure followed by Duncan's Multiple Range test (20). The 0.05 level of probability was used as the criterion for significance.

\section{RESULTS}

In the present study EAC bearing female Swiss albino mice characterized by increased size of abdomen with signs of emaciation and alopecia especially in MMC treated groups. After decapitation there was a large amount of ascetic fluid in the abdomen of mice due to EAC inoculation. 
Table 1. Showing number of mice, line of feeding, induction of cancer, treatment and decapitation time

\begin{tabular}{|c|c|c|c|c|c|c|}
\hline Groups & $\begin{array}{l}\frac{\mathscr{U}}{\Xi} \\
\frac{\dot{\Xi}}{0} \\
\dot{0} \\
z\end{array}$ & 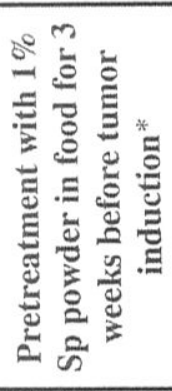 & 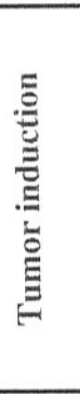 & 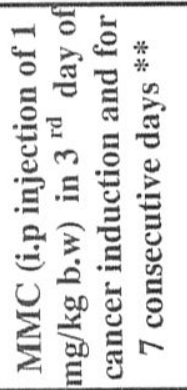 & 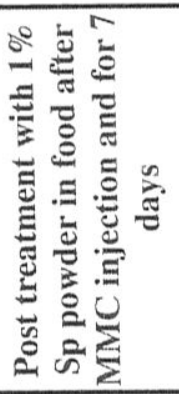 & 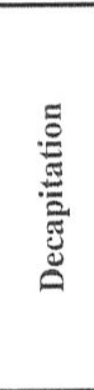 \\
\hline Control & \multirow{6}{*}{ 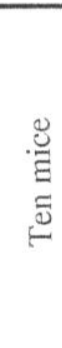 } & - & + & - & - & \multirow{6}{*}{ 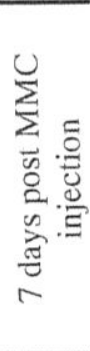 } \\
\hline Sp1 & & + & + & - & - & \\
\hline $\mathrm{Sp} 1+\mathrm{Sp} 2$ & & + & + & - & + & \\
\hline MMC & & - & + & + & - & \\
\hline $\mathrm{SP} 1+\mathrm{MMC}$ & & + & + & + & - & \\
\hline $\mathrm{Sp} 1+\mathrm{MMC}+\mathrm{Sp} 2$ & & + & + & + & + & \\
\hline
\end{tabular}

* $1 \%$ of Sp powder mixed with normal food for 24 days from MMC injection (15)

** i.p injection of $1 \mathrm{mg} / \mathrm{kg}$ b.w of MMC in third day of cancer induction and for 7 consecutive days (16).

\section{Cytotoxic studies}

Micronucleus test (MN)

There was a significant increase (p $\square 0.05)$ of $\mathrm{MN}$ frequencies in erythrocytes of MMC treated EAC mice compared with control ones. This increase was significantly decreased in combined MMC and Sp treated groups (Figs. 2 and 3).

\section{Chromosomal aberrations}

MMC induced several chromosomal aberrations which were significantly high compared to control group ( $\mathrm{p} \square$ 0.05). The aberrations include gap, ring, end to end association pulverization, hypoploidy and centromeric attenuation. Sp delivered a significant decline in chromosomal aberrations (Table 2 and Fig.4).

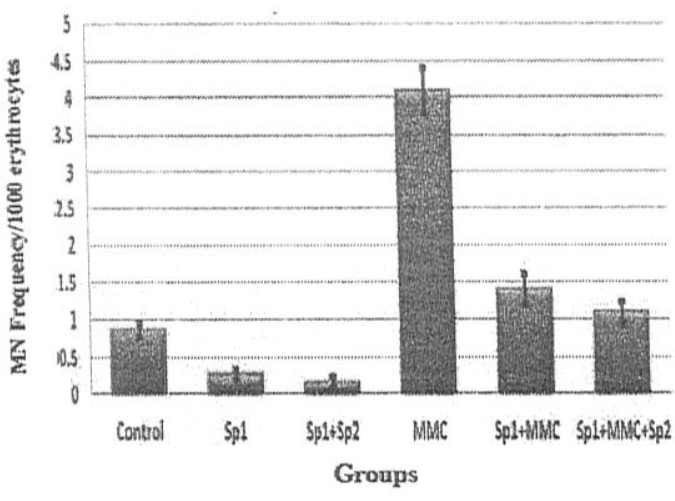

Fig.2. Effect of Spirulina platensis on MMC- induced micronucleus frequency in the erythrocytes blood smear of treated EAC bearing female mice (Means \pm S.E. $)(n=7)$. 

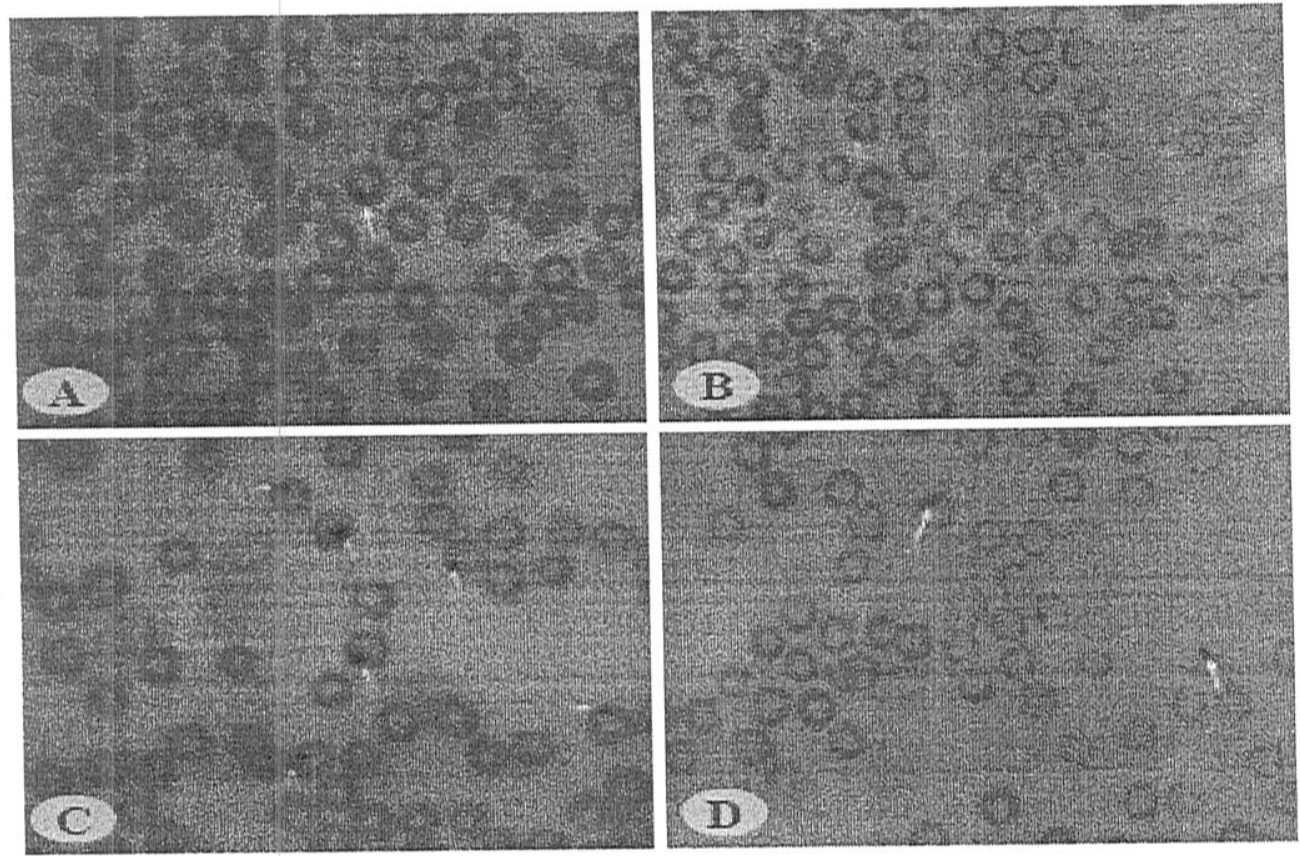

Fig. 3. Photomicrograph of blood smear from EAC bearing female mice of different group showing: A. Sporadic micronucleated erythrocyte (Control) B. Sporadic micronucleated erythrocytes as control, (Sp1) C. Numerous micronucleated erythrocytes (MMC), D. Few micronucleated erythrocytes (Sp1+MMC+Sp2), (arrow, 1000x, Giemsa stain).

Table 1.Effect of administration of Sp (1\% in diet) for 3 weeks prior to and one week concomitantly with MMC $(1 \mathrm{mg} / \mathrm{kg}$ b.wt) for consecutive 7 days on chromosomal aberrations in bone marrow of EAC bearing female mice (means \pm S.E. $)(n=3)$

\begin{tabular}{lcccccc}
\hline $\begin{array}{l}\text { Chromosomal } \\
\text { aberrations }\end{array}$ & Control & Sp1 & Sp1+Sp2 & MMC & Sp1+MMC & $\begin{array}{c}\text { Sp1+MMC } \\
+ \text { Sp2 }\end{array}$ \\
\hline TAC. & $1.40 \pm 0.61^{\mathrm{c}}$ & $1.20 \pm 0.58^{\mathrm{c}}$ & $1.0 \pm 0.45^{\mathrm{c}}$ & $10.21 \pm 1.28^{\mathrm{a}}$ & $6.01 \pm 1.14^{\mathrm{b}}$ & $6.20 \pm 0.73^{\mathrm{b}}$ \\
CA. & $2.01 \pm 1.27^{\mathrm{c}}$ & $1.61 \pm 0.75^{\mathrm{c}}$ & $2.01 \pm 0.89^{\mathrm{c}}$ & $8.01 \pm 0.89^{\mathrm{a}}$ & $4.41 \pm 0.75^{\mathrm{bc}}$ & $5.21 \pm 1.62^{\mathrm{ab}}$ \\
G. & - & - & - & $1.61 \pm 0.75^{\mathrm{ab}}$ & $1.21 \pm 0.8^{\mathrm{ab}}$ & $2.01 \pm 0.89^{\mathrm{a}}$ \\
d. & $2.01 \pm 1.26^{\mathrm{b}}$ & $1.61 \pm 0.98^{\mathrm{b}}$ & $1.21 \pm 0.80^{\mathrm{b}}$ & $6.01 \pm 0.63^{\mathrm{a}}$ & $3.20 \pm 1.02^{\mathrm{b}}$ & $3.20 \pm 0.81^{\mathrm{b}}$ \\
EE. & $1.61 \pm 0.98^{\mathrm{b}}$ & $1.61 \pm 1.17^{\mathrm{b}}$ & $2.01 \pm 0.89^{\mathrm{b}}$ & $7.61 \pm .075^{\mathrm{a}}$ & $4.01 \pm 1.26^{\mathrm{b}}$ & $4.01 \pm 0.63^{\mathrm{b}}$ \\
PULV. & - & - & - & $2.01 \pm 1.10^{\mathrm{a}}$ & - & - \\
R. & - & - & - & $2.01 \pm 0.63^{\mathrm{a}}$ & $1.21 \pm 0.49^{\mathrm{ab}}$ & $1.21 \pm 0.81^{\mathrm{ab}}$ \\
Hypo. & $1.21 \pm 0.81^{\mathrm{ab}}$ & $0.81 \pm 0.49^{\mathrm{b}}$ & $0.81 \pm 0.49^{\mathrm{b}}$ & $4.01 \pm 1.67^{\mathrm{a}}$ & $3.61 \pm 1.61^{\mathrm{ab}}$ & $3.21 \pm 0.81^{\mathrm{ab}}$ \\
TCA. & $6.81 \pm 3.56^{\mathrm{c}}$ & $5.61 \pm 2.79^{\mathrm{c}}$ & $6.01 \pm 2.68^{\mathrm{c}}$ & $31.21 \pm 2.49^{\mathrm{a}}$ & $18.01 \pm 1.67^{\mathrm{b}}$ & $18.80 \pm 1.02^{\mathrm{b}}$ \\
\hline
\end{tabular}

Means with the same row carrying different superscripts are significantly at (P $\square 0.05)$. TAC: total aberrated cells, CA: centromeric attenuation, G: gap, d: deletion, EE: end to end association, Pulv: pulverization, R: ring, Hypo: hypoploidy and TCA: total chromosomal aberrations 

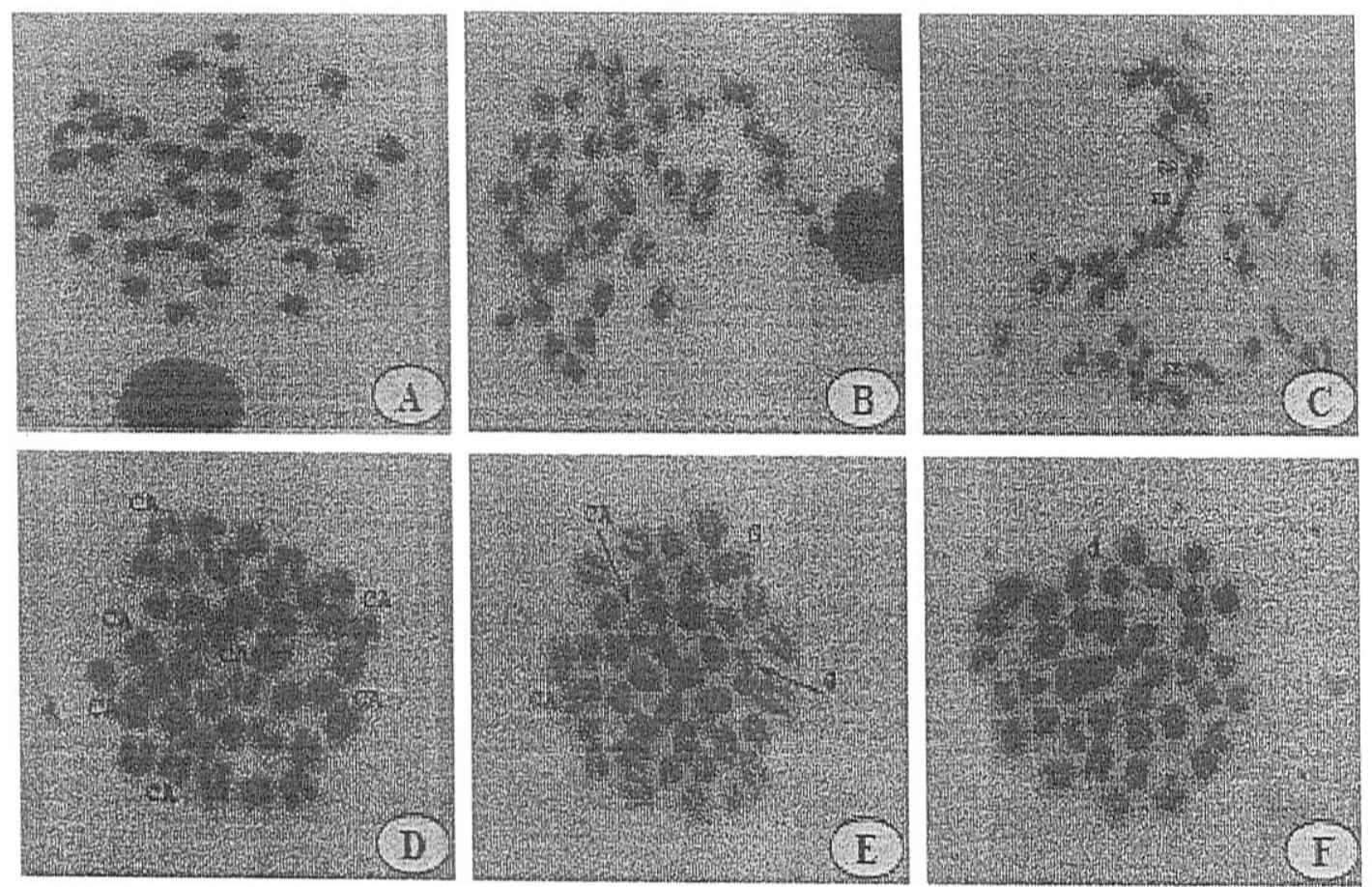

Fig. 4. Photomicrograph of metaphase spread from bone marrow of EAC bearing adult female mice $(2 \mathrm{n}=40)(1000 \mathrm{x})$ (Giemsa stain) of; A. Control group showing normal metaphase chromosomes, B. Sp1 (1\% in diet) for 3 weeks treated group showing normal metaphase chromosomes, C. MMC (1mg/kg b.wt.) treated group showing end to end association (EE), deletion (d) and ring (R), D. MMC (1mg/kg b.wt.) treated group showing centromeric attenuation (CA), E. MMC (1mg/kg b.wt.) treated group showing centromeric attenuation (CA) and gap (G), F. Sp1+MMC+Sp2 treated group showing deletion (d)

Histopathological findings

The bone marrow of control animals showed normal hematopoiesis with large number of megakaryocytes (Fig. 5,A), Sp1 treated group showed normal hematopoiesis with mild necrotic changes in the megakaryocytes (Fig. 5,B), while bone marrow in MMC ( $1 \mathrm{mg} / \mathrm{kg}$ b.wt) treated group showed moderate depletion of bone marrow core (erythroid and lymphoid cells) with individual cell necrosis. The megakaryocytes were necrotic and rarely recorded (Fig. 5,C). On the other hand the bone marrow was restored to the normal erythroid and lymphoid cells besides normal megakaryocytes in $\mathrm{Sp}$ pre- and post- treated group (Fig. 5,D).

The liver of control groups revealed round cells aggregation in the portal area with normal hepatic architecture (Fig. 6,A) and just slight congestion, Sp1 treated group showed normal hepatocytes and sinusoidal architectures (Fig. 6,B) while MMC treated group showing intense aggregation of round cells and mild biliary hyperplasia (Fig. 6,C). On the contrary, the liver of Sp pre- and posttreated group with MMC showed normal liver with little hemorrhages and extramedullary hematopoiesis (Fig. 6,D) 

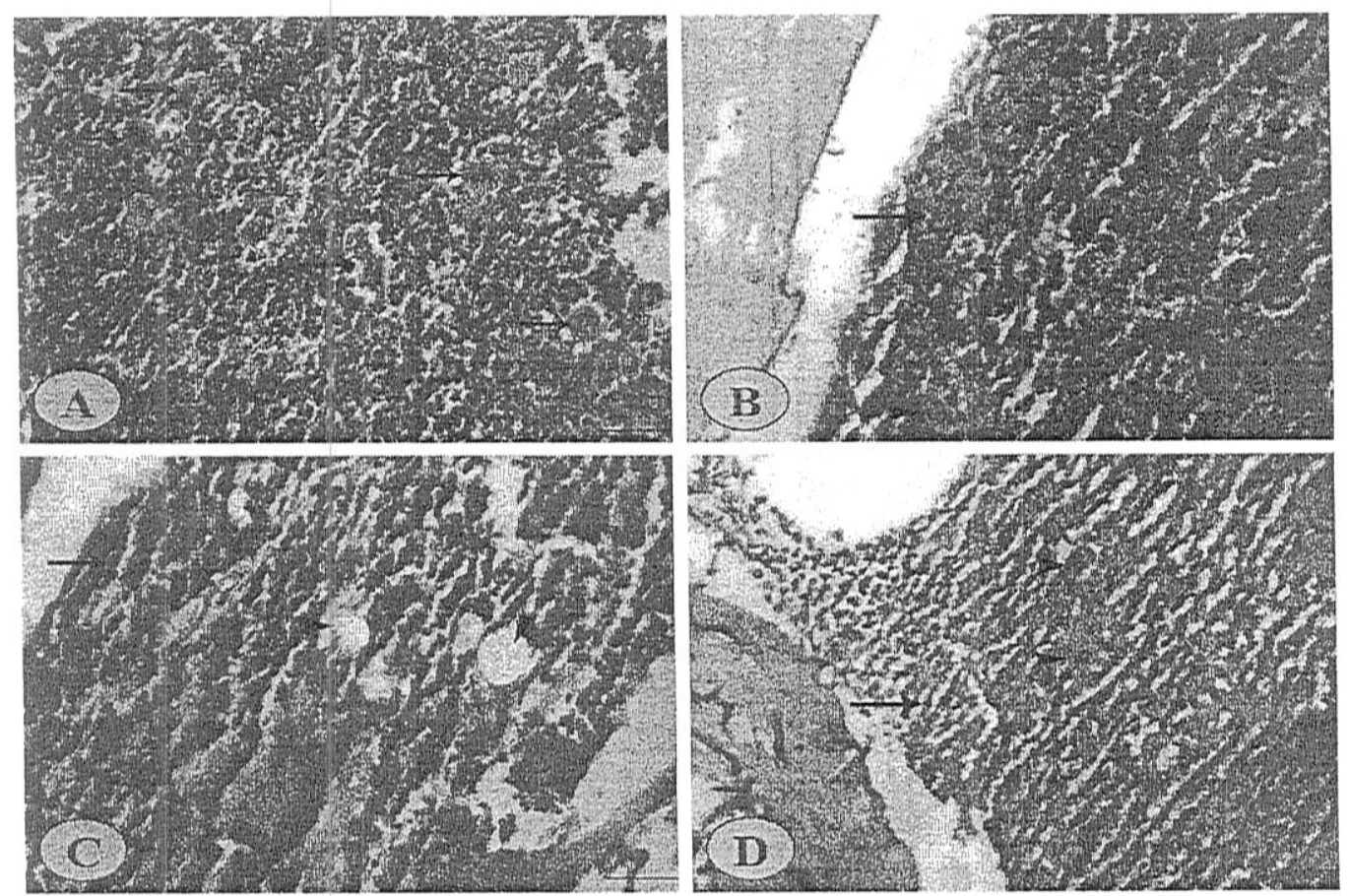

Fig. 5.Photomicrograph from EAC female mice bone marrow of

(A) Control group showing normal hematopoiesis with large number of megakaryocytes (arrows), $(\mathrm{Bar}=100 \mu \mathrm{m})(\mathrm{H} \& \mathrm{E})$.

(B) Sp1 group showing normal hematopoiesis (arrow) and mild necrotic changes in the megakaryocytes (arrow heads), (Bar $=100 \mu \mathrm{m})(\mathrm{H} \& \mathrm{E})$.

(C) MMC group ( $1 \mathrm{mg} / \mathrm{kg}$ b.wt) for 7 days showing the disappearance of the megakaryocytes (arrow), interstitial edema and increase in the fat cells (arrow heads), (high magnification) $(\mathrm{Bar}=100 \mu \mathrm{m})(\mathrm{H} \& \mathrm{E})$.

(D) Sp1+MMC+Sp2 group showing normal erythroid and lymphoid cells (arrow) with slightly decrease in the number of the megakaryocytes (arrow heads), (Bar $=100$ $\mu \mathrm{m})(\mathrm{H} \& \mathrm{E})$. 

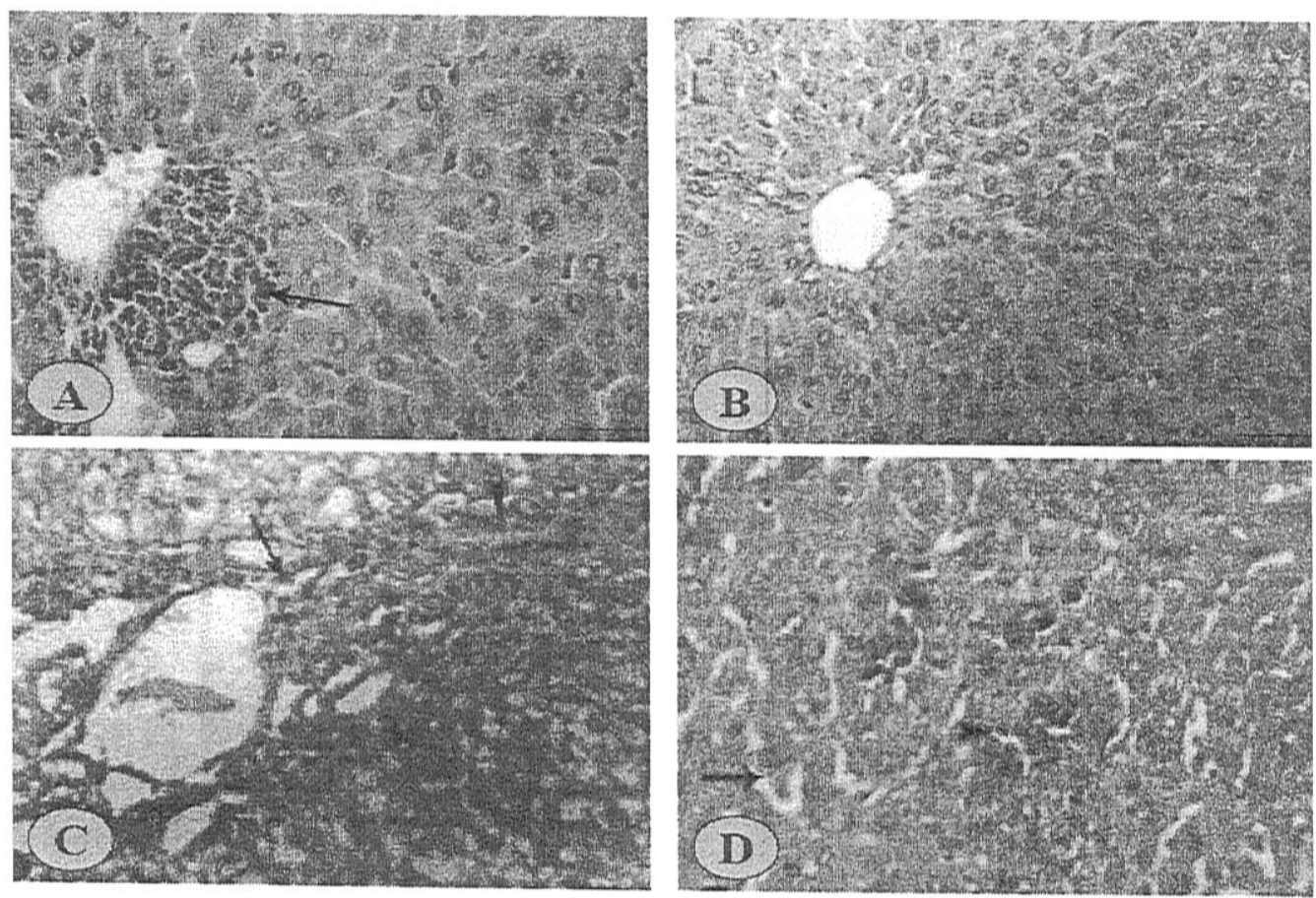

Fig. 6. Photomicrograph from liver EAC female mice of

(A) Control group showing round cells aggregation in the portal area (arrow) with normal hepatic architecture, $(\mathrm{Bar}=100 \mu \mathrm{m})(\mathrm{H} \& \mathrm{E})$.

(B) Sp1 group showing normal hepatocytes and sinusoidal architectures, $(\mathrm{Bar}=100$ $\mu \mathrm{m})(\mathrm{H} \& \mathrm{E})$.

(C) MMC group (1mg/kg b.wt) for 7 days showing portal area with intense aggregation of round cells (arrow) and mild biliary hyperplasia (arrow heads), (Bar $=100 \mu \mathrm{m})$ $(\mathrm{H} \& \mathrm{E})$.

(D) $\mathrm{Sp} 1+\mathrm{MMC}+\mathrm{Sp} 2$ group showing normal liver with little hemorrhages (arrow) and extramedullary hematopoiesis (arrow head), $(\mathrm{Bar}=100 \mu \mathrm{m})(\mathrm{H} \& \mathrm{E})$.

Concerning the kidney, in control group showed normal with slight perivascular aggregation of round cells (Fig. 7,A) and also in $\mathrm{Sp}$ treated groups showed normal glomerular and tubular structures (Fig. 7,B) while kidney in MMC treated group showed glomeruli with shrunken glomerular tufts and dilated Bowman's spaces besides vacuolation in renal epithelia (Fig. 7,C) controversially, kidney of Sp1 treated group before and concomitantly with MMC showed regenerative attempts in some renal tubule around slightly contracted glomerulus (Fig. 7,D). 

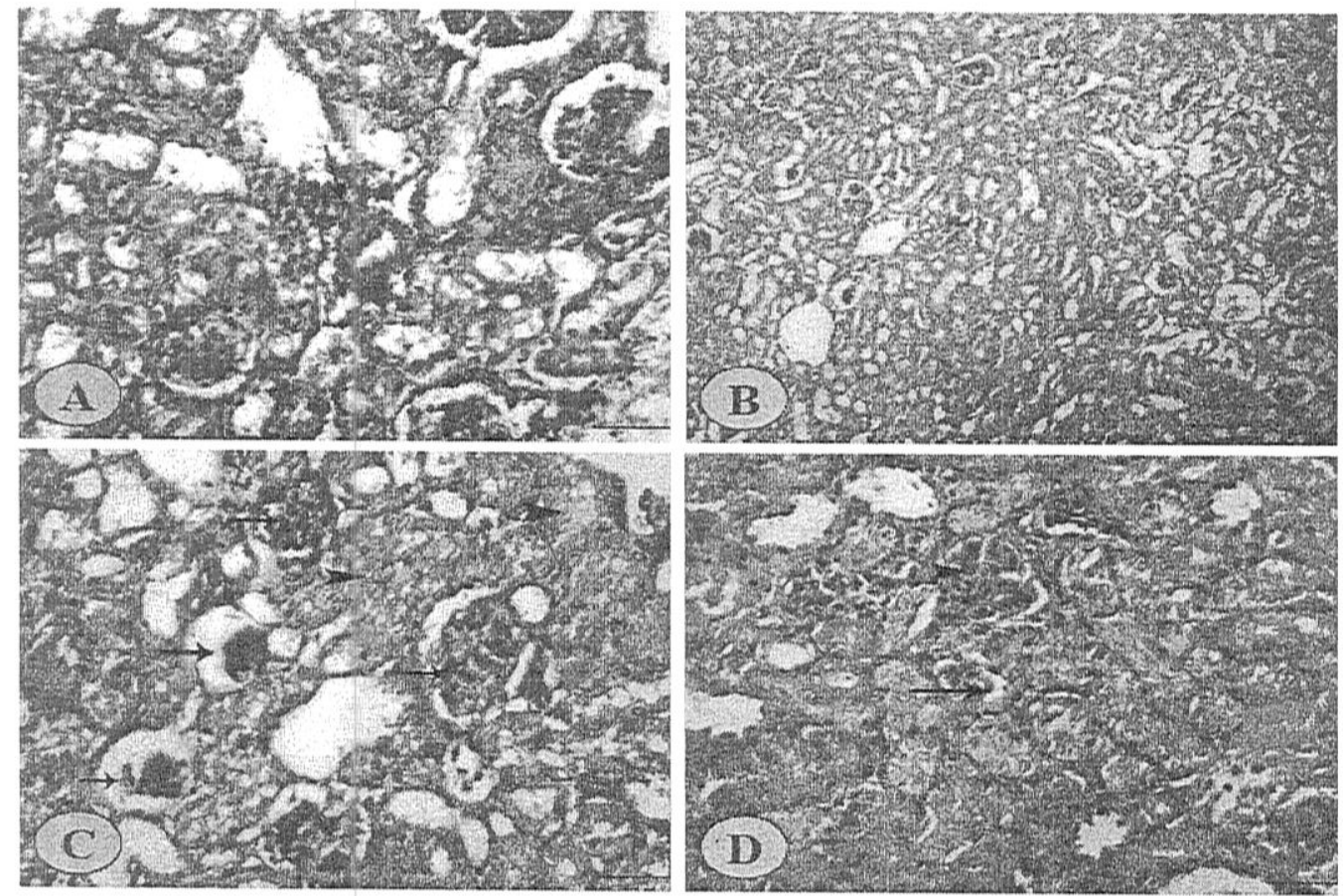

Fig. 7. Photomicrograph from EAC female mice kidney of

(A) Control group showing normal with slight perivascular aggregation of round cells (arrow), $(\mathrm{Bar}=100 \mu \mathrm{m})(\mathrm{H} \& \mathrm{E})$.

(B) Sp1 treated group showing normal glomerular and tubular structures, (Bar $=100 \mu \mathrm{m})$ (H\&E).

(C) MMC treated group ( $1 \mathrm{mg} / \mathrm{kg}$ b.wt) for 7 days showing glomeruli with shrunken glomerular tufts and dilated Bowman's spaces (arrows) besides vacuolation in renal epithelia (arrow heads), $(\mathrm{Bar}=100 \mu \mathrm{m})(\mathrm{H} \& \mathrm{E})$.

(D) $\mathrm{Sp} 1+\mathrm{MMC}+\mathrm{Sp} 2$ treated group showing regenerative attempts in some renal tubule (arrow) around slightly contracted glomerulus (arrow head), (Bar $=100 \mu \mathrm{m})(\mathrm{H} \& \mathrm{E})$.

\section{DISCUSSION}

$\mathrm{MMC}$ is a quinone-containing antibiotic; it has been used to treat a wide variety of tumors. Although current use of MMC is limited, this agent continues to be a key element in several clinical trials due to its intrinsic efficacy against many solid tumors and preferential activity in hypoxic tumoral cells. Metabolism of MMC may generate ROS, when ROS interact with cells and exceed endogenous antioxidant systems, there is indiscriminate damage to biological macromolecules such as nucleic acids, proteins and lipids (21).
Micronucleus (MN) assay and chromosomal aberration test were recommended by regulatory authorities for the assessment of genotoxicity and mutagenicity of many chemicals and natural compounds (5). MN was defined as a centric fragment of chromosome or a whole chromosome itself which lags behind in the cytoplasm during anaphase of cell division and does not get incorporated in the daughter nuclei (3). MN induction is a key characteristic of genotoxic compounds and analysis of micronuclei formation resulting from DNA strand breakage (clastogens) or interference with chromosome segregation (aneugens) (22). 
The present study showed significant increase in micronucleated erythrocytes of the blood concomitant with several chromosome aberrations in bone marrow cells of MMC treated group in comparison with control groups and these results were consistent with (21) who recorded an increase in the number of $\mathrm{MN}$ at 24, 48, 72, and 96 hours post treatment of MMC. On similar ground MMC induced breakage mainly in the pericentromeric heterochromatin (22), 18 fold increase in $\mathrm{MN}$, significant increase in hypoploidy and structural chromosome aberrations in metaphase preparations (23) and this finding was attributed to strong clastogenic effect of MMC (5). There was another explanation recorded by (24) who found that the treatment with MMC significant increase the occurrence of hypoploidy in the lymphocytes, a four-fold increase in kinetochore-positive MN in human fibroblasts. Which became in harmony with (25) who suggested that the increase in kinetochore-positive $\mathrm{MN}$ may related to the preferential binding of MMC to heterochromatin and induction of kinetochore detachment. All these previous findings have the potential to elicit aneugenic effects of MMC besides its strong clastogenic activity (26).

Controversially, the present study revealed that pre- or post-treatment with Sp had the same modulatory effect in both of micronucleated erythrocytes in blood and chromosome aberrations in bone marrow cells in comparison with MMC treated group which is in parallel to (2) who reported that pretreatment with $\mathrm{Sp}$ significantly reduced micronucleated erythrocytes, chromosomal damage and lipid peroxidation induced by cychlophosphamide and mitomycin $\mathrm{C}$ in mice when applied to bone marrow cells. The previous findings fit in with the inhibitory effect of $\mathrm{Sp}$ on the in vivo chromosomal damage $(2,10)$ beside its anti clastogenic effect (27).

Regarding to the histopathological changes, there were several damages in the bone marrow and liver including disappearance of the megakaryocytes, interstitial edema and increase fat cells in bone marrow (Fig. 5,C) with intense aggregation of round cells and biliary hyperplasia in liver (Fig. 6,C) in MMC treated group in comparison with control groups, and this is due to MMC possess a quinone chemical structure which through a cascade of bioreductive process generates hydroxyl radical $(\mathrm{OH}-)$ which potentially can damage the DNA and other biomolecules of the cell. Since, free radicals (ROS) are highly reactive they can undergo reduction by oxidation of surrounding molecules (DNA, lipids, proteins) such damages to biological molecules by redox reactions may lead to numerous pathological disorders (28). obviously, bone marrow considered the prime target organ for MMC toxicity has some pathological changes after $\mathrm{MMC}$ treatment due to the metabolic activation of MMC to 2,7 diaminomitosene which cause bone marrow cytotoxicity, anemia, increase adipocytes, decrease RBCs and haemoglobin (29). The nephrotoxic effect of MMC as vacuolation in renal epithelia, shrunken glumerular tufts in (Fig. 7,C) nearly similar to that reported in study which found that $\mathrm{MMC}$ induced hemolytic uremic syndrome due to it can directly damage vascular endothelial cells of the kidneys (30).

On the contrary, treatment with $\mathrm{Sp}$ revealed the modulation in the pathological changes caused by MMC as it act as anti genotoxic (10), anti hepatotoxic (11) and anti nephrotoxic (12), this owed to $\mathrm{Sp}$ reputed to be an external source of the vital mitochondrial antioxidant enzymes as superoxide dismutase (31) which found to quench free radicals and prevents tissue damage (32). Sp exhibited protection and regeneration of liver cells and this in consistent with (33) who reported that oral administration of water extract of $\mathrm{Sp}$ for 7 days before cadmium toxicity reduced hepatic damage and this is due to the ability of Sp to scavenging free radicals by increasing level of antioxidant enzymes, as up regulation of ROS, hydroxyl groups, superoxides and hydrogen peroxides generations which in turn lead to oxidative damage to lipid contents of 
membrane and induced liver toxicity. These characteristics can be attributed to the high levels of antioxidants such as vitamins, minerals, proteins, lipids, carbon hydrates, carotenoids and phyocyanin reported in Sp. Bcarotene decrease cell damage, especially the damage to DNA molecules, thus playing a role in the repair of the regeneration process of damaged liver cells (34). Phycocyanin pigment significantly inhibited peroxyl radical induced lipid peroxidation in rat liver microsomes (35) Sp might be applicable to the reduction of general renal dysfunction, as Phycocyanin constituent of Sp reduced the renal toxicity in rats caused by para-amino phenol (pain reliever), cisplatin (anti-cancer) (36), oxalate and mercury (32) as phycocyanin reduced lipid peroxidation concomitant with restoration of renal function tests (37).

\section{Acknowledgement}

We thank Prof. Dr. Mohamed Hamed Mohamed, Professor of pathology, Faculty of Veterinary Medicine, Zagazig University for his help in carrying out histopathological study and Dr. Mohamed Abdo Ibrahim, Researcher, Animal Health Research Institute, Zagazig Lab for his help in carrying out cytogenetic study.

\section{REFERENCES}

1.Gnad-Vogt SU, Hofheinz RD, Saussele S, Kreil S, Willer A, Willeke F, Hehlmann $R$ and Hochhaus A (2005): Pegylated liposomal doxorubicin and mitomycin $\mathrm{C}$ in combination with infusional 5-floruracil and sodium folinic acid in the treatment of advanced gastric cancer: results of phase II trial .Anticancer Drugs 16: 435-440.

2.Premkumar K, Pachiappan A, Abraham SK, Santhiya ST, Gopinath PM and Ramesh A (2001): Effect of Spirulina fusiformis on cyclophosphamide and mitomycin $\mathrm{C}$ induced genotoxicity and oxidative stress in mice. Fitoterapia 72 : 906-911

3.Mazumdar M, Giri S, and Giri A (2011): Role of quercetin on mitomycin $C$ induced genotoxicity: Analysis of micronucleus and chromosome aberrations in vivo. Mutation Research. (721): 147- 152.

4.Lee CS, Park SY, Ko HH and Han, ES (2004): Effect of change in cellular GSH levels on mitochondrial damage and cell viability loss due to mitomycin $\mathrm{C}$ in small cell lung cancer cells. Biochem. Pharmacol. 68: 1857-1867.

5.Rjiba-Touati K, Ayed-Boussema I, Guedri $Y$ and Achour A (2013): Role of recombinant human erythropoietin in mitomycin $\mathrm{C}$ induced genotoxicity: Analysis of DNA fragmentation ,chromosome aberrations and micronuclei in rat bone marrow cells. Mutation Research. 6: 1-26.

6.Verwey $J$, Vries $D J$ and Pinedo HM (1987): Mitomycin C induced renal toxicity, a dose-dependent side effect. Eur J Cancer Clin Oncol; (23) 195-199.

7.Dempsey JL, Seshadri RS, and Morly AA (1985): Increased mutation frequency following treatment with cancer chemotherapy. cancer Res., 45: 28732877.

8.Careri M, Furlattini L, Mangia A, Musc $M$, Anklam E, Theobald A and Von Holst $C$ (2001): Supercritical fluid extraction for liquid chromatographic determination of carotenoids in spirulina algae: a chemometric approach. J. Chromatogr. 912: 61- 71 .

9.Reddy CM, Bhat VB, Kiranmai G, Reddy $M N$, Reddanna $P$ and Madyastha KM (2000): Selective inhibition of cyclooxygenase- 2 by $\mathrm{C}$ - phycocyanin, a biliprotein from Spirulina platensis. Biochem. Biophys. Res. Commun. 277: 599-603. 
10.Premkumar K, Abraham SK, Santhiya ST and Ramesh A (2003): Protective effect of Spirulina on chemical-induced genotoxicity in mice. Fitoterapia 75 (1): 24-31.

11.Mohan IK, Khan M, Shobha JC, Naidu MU, Prayag A, Kuppusamy P and Kutala $V K$ (2006): Protection against cisplatininduced nephrotoxicity by Spirulina in rats. Cancer Chemother. Pharmacol. 58 (6): 802-808.

12.Khan M, Shobha JC, Mohan IK, Rao Naidu MU, Prayag A, and Kutala VK (2006): Spirulina attenuates cyclosporineinduced nephrotoxicity in rats. J. Appl. Toxicol. 26 (5): 444-451.

13.Teicher BA (1997): In "Cancer: Principles and Practice of Oncology," $5^{\text {th }}$ ed. p. 405. Lippincott-Raven, Philadelphia.

14.Zeinab EH (2009): Ginger extracts antimutagens as cancer chemopreventive agent against Ehrlich ascites carcinoma. Academic Journal Of Cancer Research, 2(2):61:67.

15.Linjawi SA (2011): Protective Effect of Spirulina Against Mitomycin C-Induced Genotoxic Damage in male Rats. Journal of American Science, 7(1): 922-931.

16.Pawar AS, Vikram A, Tribathi DN, Badmanabhat $S$, Ramarao $P$ and Jena $G$ (2009): Modulation of mitomycin C induced genotoxicity by acetyl- and thiolanalogues of salicylic acid. In vivo (23): 303-308.

17.Yosida $T H$ and Amano $K$ (1975): Autosomal polymorphism in laboratory bred and wild Norway rats, Rattus novregus, Found in Misima Chromosoma, 16: 658-667.

18.Fenech M, Chang WP, Kirsch-Volders M, Holland $N$, Bonassi $S$ and Zeiger $E$ (2003): Human micronucleus project, HUMN project : Detailed Descreption of the scoring criteria for the cytokinesisblock micronucleus assay using isolated
Human lymphocyte cultures. Mutat .Resour., (534): 65-75.

19.Bancroft TD, Stevens $A$ and Turner DR, (1996): Theory and practice of histological technique, $4^{\text {th }}$ ed., Churchill, Living Stone, New York, London. San Francisco, Tokyo.

20.Duncan DB (1995): Multiple Range and multiple F-test. Biometrics, 11: 1-42.

21.Gutiérrez $O$, López-Vicente $M$, Lostalé $F$, Fuentes-Broto L, Martínez-Ballarín E and Garcíal JJ (2009): Article Protective effect of melatonin against mitomycin Cinduced genotoxic damage in peripheral blood of rats. Journal of Biomedicine and Biotechnology; 791432: 1- 6.

22.Volders $K M$, Sofuni T, Aardema M, Albertini $S$, Eastmond D, Fenech $M$, Kirchner S, Lorge E, Morita T, Norppa $H$, Surrallés $J$ and Wakata $A$ (2003): Report from the in vitro micronucleus assay working group. Mutat. Res. 540 (2): 153-163.

23.Fauth E, Scherthan $H$ and Zankl $H$ (2000): Chromosome painting reveals specific patterns of chromosome occurrence in mitomycin $\mathrm{C}$ and diethylstilboestrol -induced micronuclei. Mutagenesis 15 (6): 459-467.

24.Rudd NL, Williams SE, Evans M, Hennig $U G$ and Hoar DI (1991): Kinetochor analysis of micronuclei allows insights into the actions of colcemid and mitomycin C .Mutant Res., (261): 57-68.

25.Brinkley BR, Tousson A and Valdivia MM (1985): The kinetochore of mammalian chromosomes: structure and function in normal mitosis and aneuploidy. Basic Life, Sci., (36): 243-267.

26.Schneider BM, Wurgler FE and Romagna $F$ (1995): Distinct area distribution differences of micronuclei induced by clastogenic and aneuploidogenic chemicals in the bone marrow of the CD-1 mouse. Mutat. Res. (334): 81-89. 
27.Ruiz-Flores LE, Madrigal-Bujaidar E, Salazar $M$ and Chamorro G (2003): Anticlastogenic effect of Spirulina maxima extract on the micronuclei induced by maleic hydrazide in Tradescantia. Life Sci. 72 (12): 1345-1351.

28.Korkina LG, Deeva LB, Biase AD, laccarino $M$, Oral $R$, Warnau $M$ and Pagano $G$ (2000): Redox dependent toxicity of diepoxybutane and mitomycin $\mathrm{C}$ in sea urchin embrogenesis. Carcinogenesis. (21): 2213-2220.

29.Adikesavan AK, Barrios $R$ and Jaiswal $A K$ (2007): In vivo Role of $\mathrm{NAD}(\mathrm{P}) \mathrm{H}$ : Quinone oxidoreductase 1 in metabolic activation of mitomycin $\mathrm{C}$ and bone marrow cytotoxicity. Cancer Res. 67: (17) 7966-7971.

30.Cattell V (1985): Mitomycin induced hemolytic uremic kidney: an experimental model in the rat. Amer. J. Path.;121: 8895 .

31.Upasani $C D$ and Balaraman $R$ (2003): Protective effect of Spirulina on lead induced deleterious changes in the lipid peroxidation and endogenous antioxidants in rats. Phytother. Res. (17): 330-334.
32.Sharma MK, Sharma A, Kumar $A$ and Kumar M (2007): Evaluation of protective efficacy of Spirulina against mercury induced nephrotoxicity in Swiss albino mice. Food and Chemical Toxicology (45): 879-887.

33.Amin A, Hamza AA, Daoud S and Hamza $W$ (2006): Spirulina protect against cadmium - induced hepatotoxicity in rats. American Journal of Pharmacology and Toxicology 1(2):21-25.

34.Luxia AS, Monica S, Ornella C, Plizzala $B$, Laura $R$, Livia $B$, Anio $M$ and Ennio $P$ (1996): Effect of b-carotene on cell cycle progression of human fibroblasts. Mutagenesis 17 (11): 2395-2401.

35.Bhat VB and Madyastha KM (2000): Cphycocyanin: a potent peroxyl radical scavenger in vivo and in vitro. Biochem. Biophys. Res. Commun. (275): 20-25.

36.Fukino $H$ (1990): Effect of Spirulina on the renal toxicity induced by inorganic mercury and cisplatin. Eisei. Kagaku. (15): 36: 50 .

37.Farooq SM and Asokan D (2004): Salubrious effect of C-phycocyanin against oxalate-mediated renal cell injury. Clin. Chem. Acta. 348 (1-2): 199-205. 
الملخص المعبى

الدور التعديلى لإضافة طحلب الإسبيزولينا القبلى والبعدى على التفيرات السمية التوراثية والمرضية لعقار

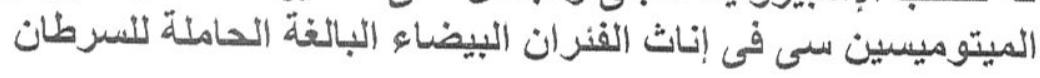

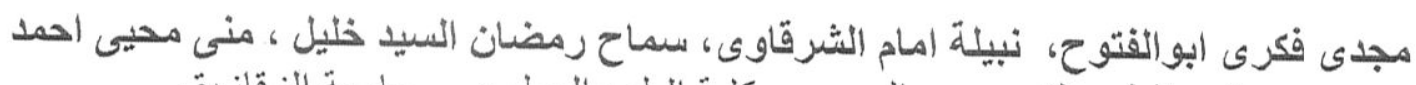

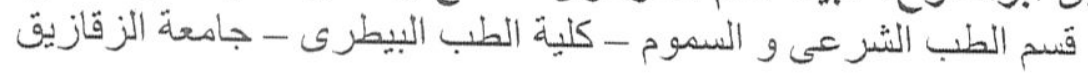

أجريت هذه الدراسة لتقصى تأثير إضافة طحلب الاسبيرولينا للعليقة قبل وبعد حقن عقار المينوميسين سى فى نخفيف التغيز ات السمية الجينية و المرضية الناتجة عن استخدامه فى اناث الفئ الفئران

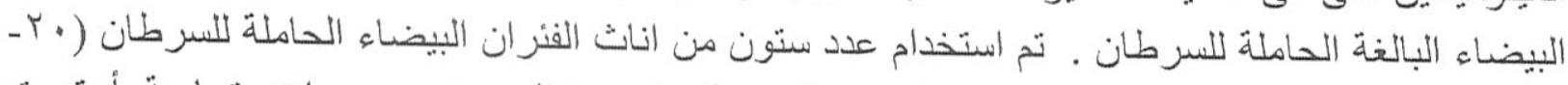
• ب جر ام تقريبا) ونت متابعتها ور عايتها خلال فترة التجربة وتقسيمها الى ست مجمو عات متساوية. أعتبرت

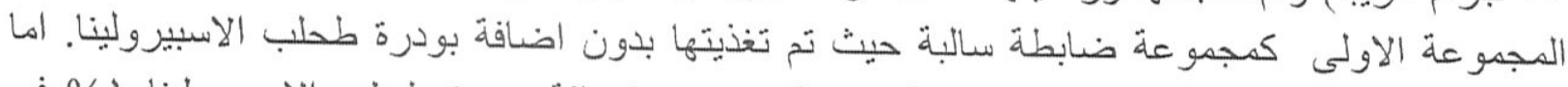
المجموعة الثانية أعتبرت كمجموعة ضابطة موجبة حيث تم اضافة بودرة طحلب الاسبيزولينا الو

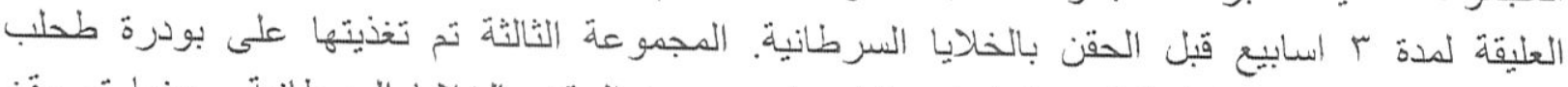

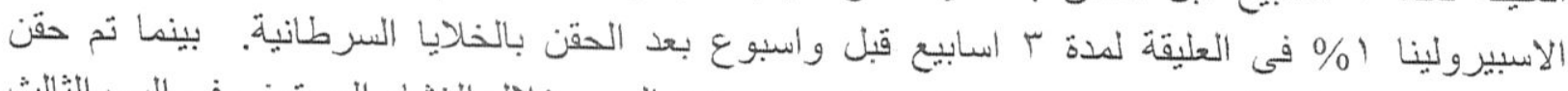
المجمو عة الر ابعة بعقار المينوميسين سى المجم/كجم من وزن الجسم خلال الغشاء البرينونى فى اليوخ الثالث

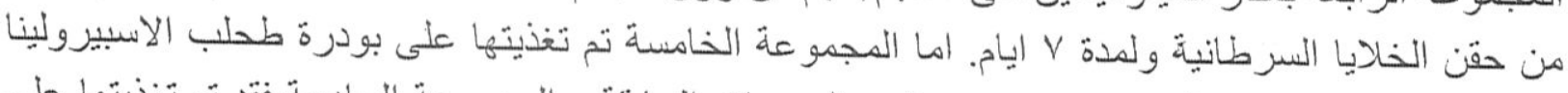

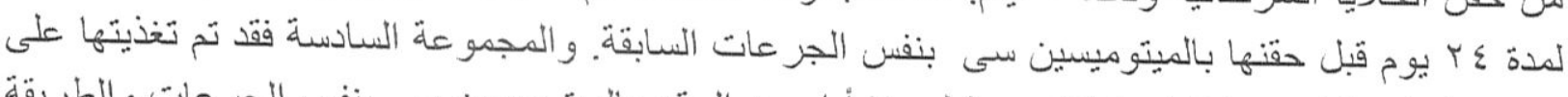

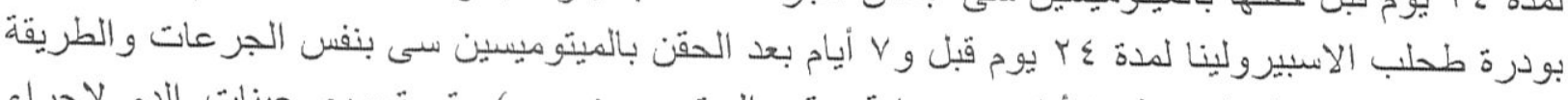
السابقة. وعند نهاية التجربة (Vأبام من بداية حقن الميتوميسين سى), تم تجميع عينات الدم لام لاجراء

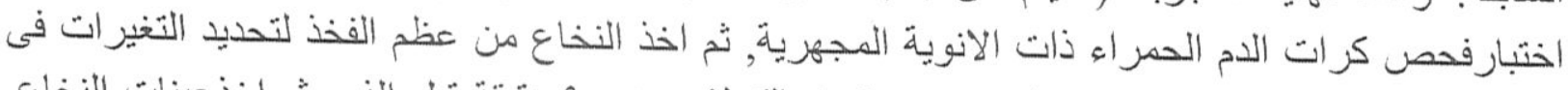

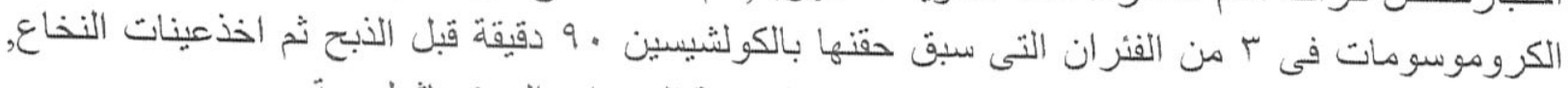

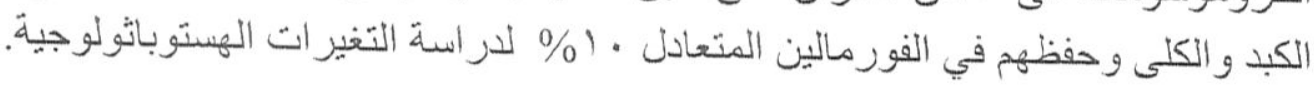

لقد أسفرت النتائج عن أن معاملة الفئر ان بالمينو مبيسين سى أدت الى زيادة معنوية فى التغيرات الجينبة

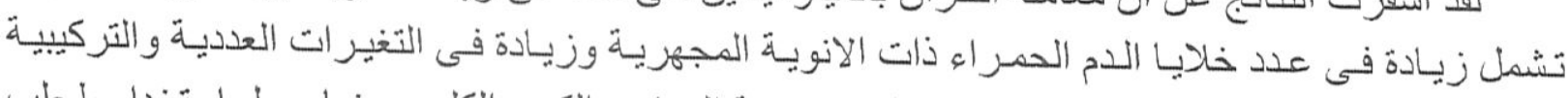

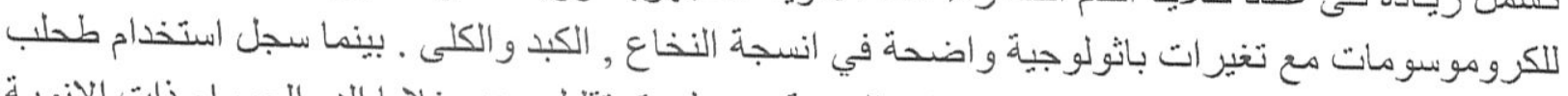
الاسبيرولينا تأثبر معنوى فى تخفيف التغير ات الجينية عن طريق تقليل عدد خلايا الدم الحمر اء ذات الانوية

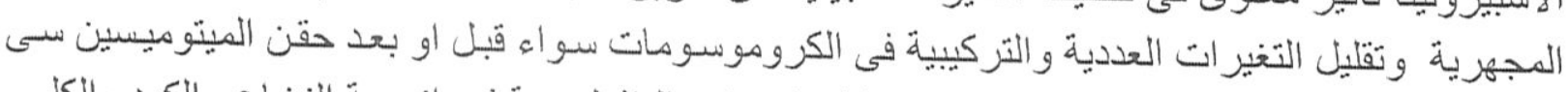

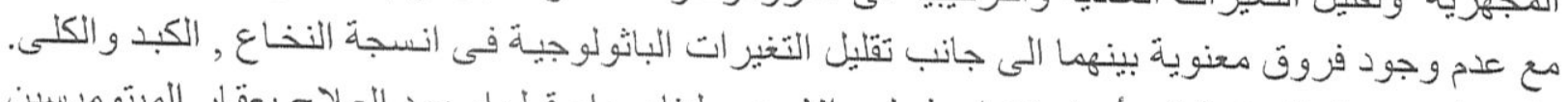
ولقد خلصت هذه الدر اسة إلي أن استخدام طحلب الاسبيرولينا سو اء قبل او بعد العلاج بعقار الميتوميسين سى فى الحيو انات الحاملة للخلايا السرطانية قادر على تقليل وتلطيف تأثير اته على الجينات والانسجة الثناء المعالجة من السرطان. لذا نوصى باستخدام هذا الطحلب قبل او قبل و بعد العلاج بالميتوسين سي. 